\title{
Proposing a Three-Dimensional Normative Model for Political Communication
}

\author{
Anastasia Veneti \\ Bournemouth University, $U K$ \\ Darren G. Lilleker \\ Bournemouth University, $U K$
}
To cite:
Veneti, A., \& Lilleker, D. G. (2022). Proposing a Three-Dimensional Normative Model for Political Communication. In D. Palau-Sampio, G. López García, \& L. Iannelli (Ed.), Contemporary Politics, Communication, and the Impact on Democracy (pp. 1-18). IGI Global.
http://doi:10.4018/978-1-7998-8057-8.ch001
(C) IGI Global

\begin{abstract}
The last ten years or more will be remembered as a time of perpetual crises. Against this backdrop, there is an urgent need for effective leadership and for citizens of the world and their leaders to come together to achieve collective goals. However, various studies have highlighted the deleterious effects on democracy of the current trajectory political discourse is taking. Increasing voices in academia call for a shift towards a more citizen-centric political communication. We respond to such calls by proposing a new model for political communication that focuses on three dimensions, namely: service ethos, inclusivity, and empathy (3D Model). In this chapter, we conceptualise these dimensions and build a normative model for their application while discuss the relevant shortcomings and current issues as they relate to contemporary political communication.
\end{abstract}

Keywords: political communication, public communication, leadership, service ethos, empathy, inclusivity, 3D model, global crisis, citizen-centric 


\section{INTRODUCTION}

In 1995, Michael Gurevitch and Jay Blumler highlighted the emergence of a crisis of public communication in liberal democratic societies. In his most recent article, Blumler (2018) contends that this crisis still persists but with a clearer focus on what he calls a "crisis of communication for citizenship" (p.83). Focusing on political communication Blumler (1997) highlighted a number of developments which he argued to be negative. Campaigning was becoming increasingly permanent, calculated attacks were made more frequently, journalists pour scorn on politicians and their publicity machines, personalization is increasing and deepening with media playing a central role in making and breaking political careers. He argued that political communication failed to meet the standards required of a democratic society and suggested the practices and tenor should be measured according to clear criteria. Does it serve citizens more than politicians and journalists? Does it offer meaningful choices between governing teams and agendas? Does it promote a broad sense of participation in government? Does it satisfy our symbolic commitment to the notion of democracy? In 1997 Blumler had hope that the pluralism afforded by digital democracy, the popular will to create better democratic structures and a return to professional codes of journalism might better align political communication with the principles of democracy. However, writing in 2018, Blumler argued each were exacerbating the problems. Digital technologies had proven to have some positive effects but far more negative ones. The popular will seemed to be moving towards a more populist position. Journalists increasingly offered blaring headlines or played devil's advocate necessarily opposing but also hectoring parties of every political colour. The crisis was worsening as a "so long as it works, anything goes!" infected politics leading to the simplification of messages and emotional manipulation of citizens. Despite the election of Trump in the US and Brexit in the UK, both of which exemplified the downturn in the quality of political discourse, Blumler remained hopeful for the emergence of a "more authenticseeming and citizenship-oriented model that favours visions and ideas for large-scale social change" (2018: 90).

Perhaps, however, the crisis is deeper. It is not simply a crisis of political or indeed public communication but part of a wider crisis facing democratic institutions. The last decade (and a bit more) will be remembered as a period of almost perpetual crises; there have been economic crises that have brought down governments; climate change and poverty are an ever present threat to societal stability; crises of international relations and national identity (e.g., Brexit) expose divisions; of privacy and technology (e.g., the scandal of Cambridge Analytica) which damage public trust; the refugee crisis, natural disasters (e.g., Fukushima nuclear disaster) and most recently the Covid-19 pandemic. Each of these have had negative impacts for public trust and support for democratic processes. Among the most malign consequences of such crises, we have witnessed the upsurge in terrorist attacks, external influences in western elections, a growing distrust of institutions and the mainstream media, increased socio-economic inequality (exacerbated by the pandemic), the growth of populism, and widespread diffusion of fake news and conspiracy theories. In particular, the current pandemic should be seen as a dual crisis: on the one hand a palpable health crisis, and on the other the economic tsunami that is just around the corner which could threaten the ability of many global citizen's access to their basic needs: food, a home, and in many cases even life itself. An interesting observation is that in the midst of this crisis we see the crucial role that the state (re)gains. Without dismissing their shortcomings, we all appreciated the financial support to businesses and employees, the significance of the National Health Systems, the overall importance of the welfare state. In a very insightful article juxtaposing the 2008 financial crisis and the current health crisis, 
Moschonas (2020) highlights how Keynesianism, in time of crises, rescued (as in 2008-9) and could rescue again economic (neo-) liberalism. He argues that massive state intervention is already taking place as the state alone has the ability to act "as the guardian of societal interests". While in the 2008 financial crisis state support was primarily directed to elites and the saving of banks, the pandemic demanded a more citizen-centric approach.

However, in view of such developments, it seems that most governments have been unable to communicate efficiently with their public. Scholarship (Sanders \& Canel, 2013; Blumler, 2018) has long pointed to the significance of government communication for human well-being. While today's visibility of government communication issues and their urgency (financial crises, the rise of populism, Covid-19 and more as mentioned above) has never been greater, governments around the world still struggle to produce effective communication, to reach, inform and mobilize citizens. While new ways of communicating with citizens, that draw on opportunities provided by new media technologies has generated considerable optimism, considerable failings in these communication practices quickly tempered the initial enthusiasm (Margolis \& Resnick, 2000). Private data breaches, extreme microtargeting, hate speech and extremism, soundbites replacing political discourse, and long standings issues such as mediatization, and the excessive marketization of political communication are among some of the developments that have triggered warnings with regards to the future of political communication. As early as 1999, researchers were calling for public administrators to no longer rely as much on the media and to develop new tools and strategies for public communication (Lee, 1999). Today, against the backdrop of a digital media ecology, Davis, Fenton, Freedman, \& Khiabanv (2020) argue that more attention needs to be paid to the negative impacts of developments in communication technology that tend to have the greatest impact upon political discourse and in turn trust in the institutions and processes of democratic statecraft.

The unfortunate results of the failings in political communication are the growing appeal of populism and conspiracy theories especially among lower sociodemographics, as well as further and widespread "disillusionment with conventional politics" (Blumler, 2018: 87). Moschonas (2020) aptly argues that "the response to a crisis is so important that it becomes - technically - an integral part of the dynamics of the crisis and a component of its very nature". Hence, we argue that communication is a fundamental and central aspect of the processes of responding to a crisis. All things considered, in order for citizens to understand and work out how best to correspond in such cases, government communication is vital, as they depend heavily on the information and interpretations they receive.

With reference to such developments, various scholars call for the need to rethink and revisit current political communication practices, along a more citizen-centric approach (Blumler, 2018) and to "re-embed an ethical code into politics" (Lilleker, 2021). In this chapter, we respond to such calls by suggesting a shift in political communication by defining this upon three fundamental and interrelated dimensions: service ethos, inclusivity and empathy. In the following sections, we conceptualise these dimensions and build a normative model for their application while discussing the relevant shortcomings and current issues as they relate to contemporary political communication. 


\section{A NEW PARADIGM FOR A CITIZEN-CENTRIC MODEL FOR POLITICAL COMMUNICATION}

In what follows we present and discuss those dimensions that we see as necessary for a shift towards a more citizen-centric political communication. We argue that the new paradigm should focus on three dimensions, namely: service ethos, inclusivity, and empathy (henceforth referring to the 3D Model).

\section{Service Ethos}

"Persuasion is achieved by the speaker's personal character when the speech is so spoken as to make us think him credible".

(Aristotle Rhetoric)

Ethos is a word of Greek origin that means morality, showing the moral character / nature of a person, group or institution (Aristotle, Book 2). The most popular use of the concept, specifically among political communication scholars, is the ethos of rhetoric as introduced in Aristotle's treatise on the art of persuasion. In "Rhetoric" (4th century BCE), Aristotle argued that persuasive communication depends on three elements, namely logos (reason in arguments), pathos (appeal to emotion), and ethos (the speaker's character). While many consider rhetoric as deceptive and manipulative, a tool of demagogues, Aristotle recognized that rhetoric itself is neutral: it can be used for good or evil, to tell the truth or to deceive (Leith, 2011). While a detailed discussion of rhetoric goes beyond the scope of this chapter, what is of interest here is Aristotle's conceptualization of ethos as the role of the character of the speaker within persuasion. In his line of thought, persuasive communication can be accomplished if the speaker appears to be credible. If this is achieved then the speaker is regarded as a point of authority and their arguments are accepted as true by the audience. However, Aristotle highlights the significance of the good character (the moral stance) in his explanation of how a speaker can appear as a credible person; he argues that they should display three things (a) practical intelligence (phronêsis), (b) a virtuous character, and (c) good will (Rhet. II.1, 1378a6ff cited in Stanford, 2010). As Mshvenieradze (2013: 1940) suggests "the impact of ethos is often called the argument's 'ethical appeal' or the 'appeal from credibility."

Other scholars have approached the concept of ethos by focusing on civic society. The importance of citizens' participation in public affairs has always been a vital element of democracy as clearly stated by Thucydides in his explicit quote "Andres gar polis", which translates as "for the polis is the men" (cited in Castoriadis, 1983: 100-101). Drawing on this, and by referring to the community of citizens' (the demos) participation in public affairs, Castoriadis (1983: 98) explains that "this participation is not left to chance, but actively promoted both through formal rules and through the general ethos of the polis". This ethos becomes an important pre-requisite for the existence of a meaningful public space; with its decisive qualities being courage, responsibility, and shame (aidos, aischune). As Castoriadis puts it (1983: 104) "Lacking these, the "public space" becomes just an open space for advertising, mystification, and pornography". Similarly, Wilson and Banfield (1971) highlighted the obligation of individuals to participate in public affairs. Drawing on, what they called, the middle-class Anglo-Saxon Protestant ethos, they conceived politics as embedding "the interest of the whole" and in that a "good government" should be characterized by "honesty, impartiality, and efficiency" (p. 1048). 
Another interesting approach related to ethos is Helms' (2012) argument about democratic political leadership. Although Helms (2012) does not explicitly refer to ethos, his discussion about authenticity and responsibility as important elements to understand democratic leadership, basically draws upon the moral aspects of the concept. He argues that authentic leadership "requires that the political actions of a leader are consistent with his or her convictions and beliefs" (p.655). Helms (2012) recognizes the importance of authenticity in the making of good democratic leadership (and as a vehicle to gain democratic legitimacy), but he also acknowledges the dangers related to this. Various scholars have pointed out that authenticity can be performed, following politicians' quest to play the role of someone real in order to appeal to their audience (Caza \& Jackson, 2011; Coleman, 2011). Such arguments are enhanced by those who are dubious of the conception of authenticity as the idea of one being true to oneself, and rather understand authenticity as a social construct "encompassing the degree to which someone is and remains true to himself or herself" (Lubke, 2020:2). The concept of authenticity has attracted wider scholarship attention in political communication and very much so in examinations regarding populist leadership (Enli \& Rosenberg 2018; Shane 2018). With reference to populist leadership, De Beus (2009:100) suggested we witness a 'new political culture of authenticity'.

As for Helms' (2012) approach to responsibility, he highlights the significance of integrity and consistency between words and actions. This aligns to the concept of a public service ethos which implicitly is at the heart of the ideal representative democracy. However, he presciently argues that even though politicians are aware they are being closely monitored by the media, and even more fiercely exposed through social media, they quite often fall into actions of irresponsibility. The accusations that Greek Prime Minister Kyriakos Mitsotakis violated his government's pandemic restrictions, revealed in a viral video showed the Greek PM attending a lunch during a visit to a Greek island that far exceeded the limit on gatherings at a time that government had further tightened restrictions to reduce virus transmission (Holroyd, 2021). Similarly, Dominic Cummings, special advisor to British Prime Minister Boris Johnson, was revealed to have broken not only the spirit of rules but the law during national lockdown, yet he was subsequently defended by Johnson and kept his job. The examples are illustrative of these leader's failure to adequately perform authentic leadership and responsibility (as described by Helms, 2012), and offer the impression that rules applied to the masses do not apply to those in or close to government. Despite both governments attempting to explain the situation, Mitsotakis and Johnson faced mounting anger both from media and opposition parties, and a growing distrust from the general public. The inconsistency between the PM's rhetoric (numerous public addresses emphasizing the importance of individual responsibility) and their subsequent explanations of clear breaches of their own rules and guidance defined the people's perceptions. The Covid-19 pandemic has stressed, more than ever before, the need for effective and consistent public communication, especially as political leaders are under constant scrutiny.

What the above examples emphasize is one that goes to the heart of the crisis for democracies: public trust. Political leaders may follow Aristotelian guidelines when performing authenticity, however their performance of governance can appear, or be, at odds with their rhetoric. While the media spotlight may make politicians appear corrupt and venal due to blaring headlines, the fact that there are real instances of corrupt practices, cronyism, broken promises and failings in accountability demonstrate that the performed ethos is inconsistent with actual behaviour. Hence, we stress the need for honesty instead of authenticity. The literature discussing authenticity shows it to be a vague and contested concept with a strong link to the fabrication of a public image. Honesty better captures the qualities required in our communication model. 
That is we espouse that ethos should follow what Mshvenieradze (2013:1940) argued to be a composition "of correct attitudes, respect [...], ethics". Returning to the classical definition of ethos, honesty is about moral character that includes or relates to other traits which the public seek in their representatives, in particular integrity, truthfulness, responsibility and accountability. Integrity, as Lubke (2020:3) argues comprises the "idea that individuals act according to their principles". Political actions should be consistent with one's values and beliefs. Also, Helms (2012) discusses responsibility as not just taking responsibility, a core part of being seen to be accountable, but also being a responsible leader. Here we can connect responsibility to the Greek concept of practical intelligence (phronêsis) but perhaps also include the notion of emotional intelligence which is at the heart of the pathos dimension of Aristotle's model for the rhetorician. Finally, also important are courage and shame (Castoriadis, 1983). It takes courage to take bold decisions, related to responsibility, but these have to be communicated and understood as for the good of the general public. Similarly, demonstrating the ability to feel shame means a leader shows they understand their responsibilities and is willing to be held accountable, again this relates to an ethos of integrity and demonstrates having a good and moral character. Thus, ethos needs to be placed at the heart of political communication but ethos cannot simply be performative. An ethos of integrity, truthfulness, responsibility, accountability, courage and shame, an ethos imbued with morality needs to be at the heart of governance. If this is lacking, communication can never appear to be honest and governments who are perceived as lacking this ethos will not be trusted to act on behalf of the greater good of their citizens.

\section{Inclusivity}

As discussed above citizens' participation in public affairs has always been a crucial element for a democratic society. Drawing on this premise our second dimension is the need for inclusivity in political (public) communication. The idea of inclusivity and an inclusive society has been widely discussed by both political and communication scholars. In a 2009 report, United Nations defined an inclusive society as a "society for all in which every individual, each with rights and responsibilities, has an active role to play" (p.7). In an inclusive society, regardless of their backgrounds (race, ethnicity, religion, gender, social status, (dis)abilities, or sexual orientation), all citizens are equally able and motivated to participate in civic, social, economic and political activities. This report also discussed the critical elements necessary to create an inclusive society, and in the importance of various actors amongst which the media and governments hold a crucial role. For the scope of this chapter, we are concerned with two things mapped out in this report:

(a) The creation of the conditions that would enable all citizens to participate in every aspect of life as well as in decision-making processes;

(b) The importance of well-informed citizens as a condition to maximize participation in public affairs. "Publication/information sharing and increasing the accessibility of the community's activities will eliminate doubts and suspicions which could otherwise create a sense of exclusion" (UN Report, 2009:15).

While in principle many democracies have policies in place to ensure all citizens have the practical means and education to participate in politics these are uneven and proven to be unsuccessful. Kemmers (2017) argues that one of the key explanatory factors for citizens to abstain from voting or vote for populist parties is their perceived lack of agency and empowerment. Put simply they feel that political parties and state institutions are not interested in responding to their concerns, and so feel marginalized and disenfranchised. Well-cited examples of US presidential candidates arguing that $47 \%$ of the population are not part of their 
electorate or describing an opponent's supporters as a basket of deplorables are used to demonstrate the use of exclusionary language which reveals the thinking within that bipartisan system (Blake, 2016). Exclusionary references may just reinforce perceptions of citizens that one party or another does not see them as valuable at elections. However, it is argued that many communities, due to myriad characteristics including social class, ethnic background, religion or culture, feel excluded from the system (Bay \& Blekesaune, 2002). While their guidance particular pertained to the crises caused by the Covid-19 pandemic, the team of social psychologists who authored Together Apart highlighted the importance of weness as a central concept for governance. Political leaders need to establish themselves as a central unifying figure able to embody 'representing us', 'doing it for us' and 'crafting and embedding a sense of us' in all communication (Jetten, Reicher, Haslam, \& Cruwys,

2020: 25-30).

The link to our conceptualization of a normative perspective of ethos is obvious here. While most important in times of crisis, though one may argue that many governments have faced perpetual crisis for the last decade or so, the inclusive notion of we-ness should be at the heart of democracy. Put simply, if the tone of any language or impacts of any policy do not offer inclusive benefits, and marginalize some groups, the policy and government may be viewed as illegitimate. As democracy rests on the legitimacy of elections and a utilitarian philosophy of governance this is crucial. We-ness is encapsulated by Jetten et al (2020) as clear, coherent and empathic communication which unites all people behind a common goal, with behavioural change facilitated, underpinned by clear evidence to support decisions taken. As highlighted when discussing ethos, leaders must stand as exemplars for the emotional and behavioural responses that should be adopted across the community. Reflecting on the handling of the pandemic in the UK, one of the team of authors of Together Apart, Professor Stephen Reicher, tweeted in summer of 2020 that Boris Johnson had trashed all the principles within the work. To some extent this is an assessment that applies to many leaders (Lilleker, Coman, Gregor, \& Novelli, 2021).

Inclusivity is perhaps of even greater importance as the nations of our world emerge from the pandemic. Studies show that social inequality has increased during the pandemic and the most socially disadvantaged have been hit worst (Social Mobility Commission, 2021). There are serious disparities between nations, The Guardian reports that "coronavirus could turn back the clock 30 years on global poverty" (Spinney, 2020) but also within nations. Not only have those existing on or below the poverty line been more likely to die of Covid-19, they are also most likely to feel the worst effects of the locking down of the economies and the collapse of businesses during that period with fears many could find themselves homeless and jobless once government support mechanisms end (Degerman, Flinders, \& Johnson, 2020). Those who fall into the worst hit demographics are also found to be those with lower trust in democratic institutions and to whom populist, nationalist and anti-democratic arguments most appeal, in other words they are demographics whose practice is shaped by perceived political marginalization (Norris \& Inglehart, 2019). Hence those who already feel marginalized are likely to experience a further and more devastating set of experiences.

At times of crisis, and in particular when a crisis coincides with a period when a nation has become politically polarized, leaders need more than ever to develop an inclusive and uniting mode of communication. Feminist studies have provided us with useful insights regarding communicative action as a more inclusive concept and have allowed for a better understanding of the (dis)functioning of the public 
sphere in contemporary societies (Pajnik, 2006). Bickford (1996) extends Habermas' theory of communicative action by enriching his concept of speech action with that of political listening as an activity. Her conceptualization of this activity involves an active willingness to construct relations of attention and implies that the speaker and the listener are 'different but equal' (Bickford, 1996: 23-24). Following her argument, like-minded scholars argue that this can be recognized as "a practice of citizenship, which is based on attention to the perceptions of others and at the same time on the redirection of attention from the subject to the world" (Pajnik, 2006: 391). In the same vein, feminist scholars proposed the concept of the ethics of care as an alternative to the Habemasian ethics of justice in an attempt to achieve greater openness and inclusivity in communication. Their approach suggests further that the polyphony of voices and rational argumentation, which constitute fundamental components of Habermas' communicative action, should recognize the importance of emotion and mutual understanding (Verstehen) as a process (Pajnik, 2006). In this context, Chambers (1995: 176-177), who argued for public debate as a 'democratized forum', called for the active engagement of excluded voices, the opening of opportunities for action, the politicization of the depoliticized. To extend political communication along these lines, Young (2000) proposes three modes of action, namely, greeting and public acknowledgement, affirmative rhetoric and narrative and situated knowledge. Greeting is an expression of acknowledgement of discourse that "implies a recognition of individuals in their particularity" (Pajnik, 2006: 394). Affirmative rhetoric refers to rational argumentation together with emotion and performative politics. In this case rhetoric "relates to reflexiveness in the sense of active listening to various speakers"; bringing inclusiveness into communicative action "since it is based on the active recognition of the specificity of context and the positioning of political actors" (Pajnik, 2006: 394). Finally, narration and story-telling are proposed as a powerful strategy to uncover injustice and systemic mistakes; a way to give voice to marginalized groups, for example migrants.

So, while a more inclusive and 'representative of all people' approach needs to be adopted by politicians, further action needs to be undertaken in order to secure those necessary conditions that would enable, as well as motivate, citizens to feel sufficiently empowered to participate in public affairs. Civic participation lies at the heart of democracy, and for that a vivid public sphere where citizens exchange views and knowledge, based on equal rights and obligations, constitutes a pre-requisite for a healthy community (Habermas, 1989). However, as Castoriadis (1983:104) rightly ponders: "The existence of a public space is not just a matter of legal provisions guaranteeing rights of free speech, etc. Such provisions are but conditions for a public space to exist. The important question is: What are the people actually doing with these rights?". To answer this question, Castoriadis $(1983$; 1991) points to education and more specifically to paideia. Paideia is a term that originates in ancient Greece, it refers to an all-round civic education that encompasses a life-long process of character development (Fotopoulos, 2005). Paideia is a much broader term that goes beyond academic credits, as it "involves becoming conscious that the polis is also oneself and that its fate also depends on one's mind, behavior, and decisions; in other words, it is participation in political life" (Castoriadis, 1983: 104). Societies operating in this way will adopt the view that politics is an activity undertaken by every individual, as opposed to being seen as the preserve of a very particular political class.

To attain such a society, the operational rules of the entire information environment need to be considered. For citizens to actively participate in public affairs, and to be in a position to interrogate laws, reflect and deliberate, they need to be adequately informed; and in that, the role of the media is of equal importance to 
that of politicians. Discussions around new media's task to provide all citizens the information they require in order to participate in democratic governance has long been central in political communication studies (Blumler, \& Gurevitch, 1995; Davis et.al., 2020). Media's role is to ensure that citizens can draw upon a 'diverse marketplace of ideas' in order to form opinions, vote for candidates and engage in political life (Stromback and Kaid, 2008 cited in Rupar, Owen, \& Baker, 2015: 5). As Rupar, et.al. (2015) argue, such information diversity "associated with the spectrum of political options and equal access to political and media arenas, promotes the idea that virtues of tolerance and respect for 'otherness' allow harmonious functioning of society and put a barrier to discrimination on any ground." However, news media have long been criticized for failing to appropriately respond to their role in society. A disproportionate preoccupation with personalities over policies, an obvious preference for conflict over discussion, frequent propagandistic rhetoric, favouritism towards specific politicians, and the marginalization (if not silencing) of anti-establishment voices are among the many criticisms that have been attributed to political journalism (Curran, Iyengar, Lund, \& Salovaara- Moring, 2009). For an inclusive society, media should overcome corporate interests and political biases, and fulfill their normative role, which is to provide accurate, fair and impartial information. Information sharing and accessibility, the nourishing of a forum for public debate can facilitate and promote citizens' participation in public life.

\section{Empathy}

Empathy derives from a Greek word meaning "to make suffer" and requires personally feeling and speaking to the emotions of another person. Empathy should not be conflated with sympathy, a feeling of compassion, but denotes understanding and sharing feelings within a particular context. Hence, Hoffmann (2000: 4) describes empathy as a self-aware congruence of emotions which acts as a guide on behaviour. In other words, in order to be a good and moral leader, that leader must experience empathy for the people they serve (Hoffmann, 2000: 17). Empathy is thus crucial for inclusivity, as it permits a leader to understand the entirety of those they serve through their performance of governance while also ensuring communication from leader to citizen invokes the crucial pathos dimension at the heart of Aristotelian rhetoric (Shogan, 2009). People seek leaders that inspire them, as well as seeking coherent and convincing explanations of decision making to help them understand the workings of their society, especially under extraordinary circumstances (Jetten et.al., 2020). Aligning empathy with pathos suggests a strategic construction of the tone of communication to reflect the mood of a specific audience. While a natural part of the rhetorician's toolkit, scholars point to a broader definition suggesting that empathy is not simply a reflection of a mood but the values of the people (Gerodimos \& Justinussen, 2015). There is evidence of leaders, and particular candidates for office, telling people what the values of the nation are, should be, or will be if they as candidate are elected (Waheed, Schuck, de Vreese \& Neijens, 2011). However, research suggests that effective leadership, trusted and transformational, is built through the communication of 'weness'. In other words, there is no separation between leader and follower, leaders represent everyone, act in the way anyone would and demonstrate how 'we' is reflected within word and deed (Van Dick, et al. 2018). In many ways this goes beyond communication and to the character of the leader, they cannot see themselves as exceptional or above the masses but of and as one with the people (Jetten, et al., 2021: 28). This aligns empathy with authenticity, but not as a device of communication but as a philosophy of performing the role of leader. 
Perhaps this highlights the problem, leaders through their performance must bridge the roles of ordinary person and that of the superhuman with the ability to provide the leadership the people need at any given time. The challenges of performing both simultaneously, and the scrutiny that their performances are given, contribute to what appears to be a crisis in terms of perceptions of leaders and the degree of empathy they possess. Firstly, research shows that political and economic elites are perceived to lack empathy due to them being seen as remote and out of touch with the masses in a society (Reiser, 2018). When they express empathy, it is viewed at best as sympathy (as they lack understanding of the lives of ordinary people) or a rhetorical devise designed to manipulate. With the widespread knowledge of the revolving door between politics and business and the self-sustaining nature of elites within nations (Verzichelli, 2018) the perception is reinforced that those in power are a cabal who promote their own shared interests as opposed to concerning themselves with those of the people. Such feelings if they spread within a society fuel mistrust, support for anti-elite populism and provide a basis for beliefs in conspiracy theories about corruption and the machinations of deep state forces (Castanho Silva, Vegetti, \& Littvay, 2017).

The cataclysmic repercussions of the Covid-19 pandemic have highlighted more than ever before the significance of empathy in political (public) communication. Research (Yang \& Mutchler, 2020; Cooke, Eirich, Racine, \& Madigan, 2020) has demonstrated fundamental behavioural changes and rise of negative feelings (such as increasing stress, uncertainty and fear) amongst the population following the perpetual lock downs, social isolation and economic insecurity. During such times, public communicators need to engage with the emotional mood of the public and, as stated above, turn 'sympathy' into empathy. As in every crisis (but not only during crises), political leadership needs to be able to appreciate and understand people's feelings, and that should be reflected both in decision-making as well as through communication. Various political consultants have now grasped this need. As Tsaoussakis (2021) aptly suggests, political communication ought to "be built on values of collective good, to position the citizen and their needs in the center". And in that we totally agree, as it is exactly this ability and flexibility to understand the citizens and the fluctuations in their feelings that can make for an effective and sustainable political communication.

Therefore, while the pandemic has harshly tested the communication and leadership abilities of political leaders globally, it comes as no surprise why New Zealand's Prime Minister, Jakinda Ardern, has been widely praised as the most effective political leader primarily thanks to her empathetic approach. It is most possibly Helen Clark's (former New Zealand's PM) response to The Atlantic, when asked about Ardern, that best explains Ardern's successful approach: "People feel that Ardern doesn't preach at them; she's standing with them" (Friedman, 2020). As McGuire at al. (2020) research demonstrate, Ardern understood the citizens and was equipped with the necessary flexibility to adapt to changing circumstances. According to their findings, Ardern's crisis leadership was discerned by different phases defined by the conditions, in that in the early phase, she sought to "reassure the public in relation to the government's decisiveness and evidence-based approach", while during the later phases, she shifted "towards a more empathetic approach encouraging solidarity among the community and a common understanding on how people should make sense of the situation" (McGuire, Cunningham, Reynolds, \& Smith, 2020:374). McGuire et al., (2020) highlight that Ardern's quality is not just appearing authentic but acting authentically as the comforter and counsellor, displaying human fears and vulnerabilities without appearing weak, and speaking a shared code of language. 
We therefore argue that there are two interrelated aspects within empathy that we need to consider in order to fully comprehend and practice it in political communication, that is (a) the need to initially understand how people feel, and (b) to communicate the messages in an empathetic way. With regards to the first aspect, this cognitive process of understanding citizens' emotions constitutes a pre-requisite to then move on to the second process which is developing a language and tone for communication. Knowing and understanding one's people can then guide the construction of clear consistent messages to be communicated in an empathetic manner. The appropriate language and tone can help frame a shared reality and allow sensemaking especially during critical situations (Whittle, Housley, Gilchrist, Mueller, \& Lenney, 2015). Empathy can be a powerful tool for building perceptions of effective leadership. As Shogan (2009: 860) argues "Empathy has the power to alter opinions, strengthen relationships, and foster an understanding of unshared circumstances or experiences."

Empathy is thus a crucial component of the ethos of political leadership, and at the heart of honest authenticity. Through empathy the leader demonstrates their emotional intelligence and pathos, a core component of persuasive but trustworthy communication which builds a relationship between the speaker and audience based on shared understanding and experience (Miao, Humphrey, \& Qian, 2018). But as with ethos and inclusivity it cannot simply be a rhetorical device. Public policy should champion collective interests ensuring no-one is left behind (Steffens, Mols, Haslam, \& Okimoto, 2016) and this is as stated even more crucial as economies and societies emerge from the pandemic. Importantly however policy cannot adopt a one size fits all approach. Empathic policy making involves building an understanding of the contexts of each community within a nation into decision making. Hence there are strong links between empathetic communication and policy making, a demonstrable ethos of honest and moral governance and inclusivity.

\section{CONCLUSION}

This chapter constitutes a response to increasing voices in academia (Blumler, 2018; Davis et. al., 2020; Lilleker, 2021) calling for a need for change, pointing to a range of empirical studies which highlight the deleterious effects on democracy of the current trajectory political discourse is taking. Beyond academic discussions, it is reality itself which emphatically points to the need to do things differently. The last ten years and more will be remembered as a time of crises; of poverty, migration and population displacement; of international relations; of privacy and technology; and of public health. Some crises are long lasting and unsolved global problems that will only exacerbate unless drastic measures are undertaken. Others incrementally undermine and erode trust in national and international institutions. Cumulatively, however, the confluence of crises is like nothing we have experienced before outside of wartime. Against this backdrop, there is an urgent need for effective leadership and for citizens of the world and their leaders to come together to achieve collective goals. In doing so, as Jetten et. al., (2020:32) argue people would "look to others — and to leaders in particular — to help them understand what they should be thinking and doing, as well as how their actions contribute to a concerted societal response."

Coming together to generate a concerted, globally relevant societal response is ambitious and challenging. But we argue such initiatives need to begin at a national level. It is not only a matter of changing policy but also the nature of political discourse. It necessitates ensuring politics is something everyone can and wants 
to engage in. Drawing on such arguments, we propose the three-dimensional (3D) normative model for political communication (see Figure 1) that emphatically points to a more 'ethical' turn in communication processes, in the sense of inviting all actors involved to undertake responsibilities as well as re-positioning the citizen at the center of public life and political communication. Our suggestions are based on the premise that we need a more sustainable political communication; one that will be able to respond to the challenges ahead of us.

3D Normative Model for Political Communication

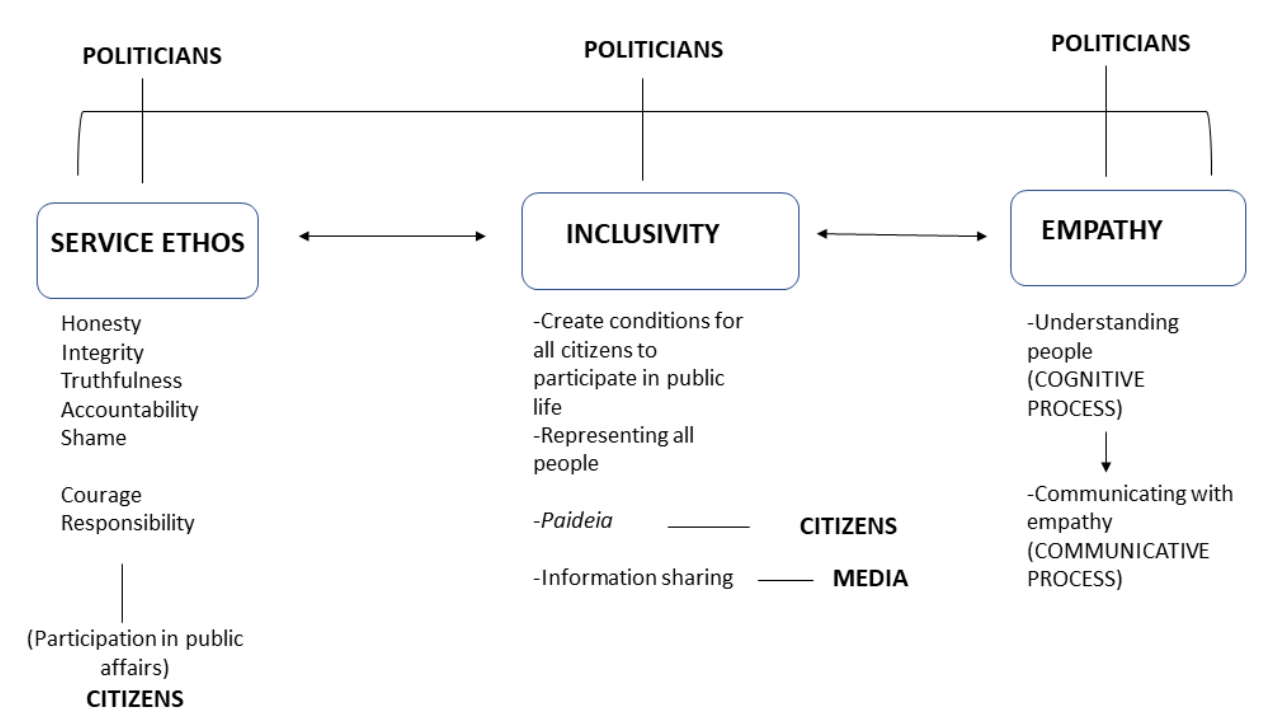

Figure 1: 3D Normative Model for Political Communication

The three-dimensional model highlights the three principles that need to permeate political communication, namely: service ethos, inclusivity, and empathy. While there may be other possible dimensions that could secure a sustainable model of political communication as well as good and effective democratic political leadership, we argue that the above three appear to be of particular relevance to the current state of affairs. The suggested dimensions are interrelated and should be read as such.

Our conceptualization of service ethos draws primarily upon the character of the speaker (as per the classic conceptualization by Aristotle), and the need for politicians to espouse honesty, integrity and accountability (Helms, 2012; Mshvenieradze, 2013), but we also embrace those approaches that focus on the role of the civic society. In that, the obligation of citizens to participate in public affairs is of paramount importance in a democratic society. Albeit in different ways, all actors involved should perform their rights and obligations in society by taking responsibility for their actions, by taking the courage to actively participate in public affairs. Yet, it is largely the responsibility of politicians to create those conditions necessary for the people to participate in public affairs. To secure a more inclusive society - one where all people feel they are properly represented - politicians and leaders should embrace the notion of we-ness (Jetten et. al., 2020). We acknowledge that total inclusivity is a major challenge and may never be actually achievable, 
there is plenty of space for politicians to foster inclusivity. However, it represents a core criterion for government to earn political legitimacy, and it can only be earned through interaction with the citizens, listening to them and responding following a process of understanding. A sense of belonging has proven to be a trigger for active civic engagement and political participation (Lehavot, Balsam, \& Ibrahim-Wells, 2009; Ball-Rokeach, Yong-Chan \& Matei, 2001). For that to be achieved, inclusiveness should permeate the overall communication philosophy and subsequently demonstrated through the act of speaking. Concurring with Young (2000), an inclusive model of political communication should embrace emotion in the form of empathy (including emotion and expressiveness) and marginalized groups' voices and relevance (such as migrants, LGBT etc.) should be appropriately politically acknowledged. Top-down rhetoric from leaders expressing their own exceptionalism, and the distillation of complex societal issues into simple messages have been proven to be inadequate in contemporary multicultural and diverse societies.

To further cultivate such an inclusive and democratic environment, political actors should nourish and promote civic participation through the broader education of the citizenry (as encapsulated in the concept of paideia), and by providing citizens with access to impartial and reliable information. To achieve the latter, media should play their role in serving the public interest. Finally, empathy is key to inclusivity as it allows a leader to understand those they serve. Empathy can be achieved through a two-level process; it initially requires the understanding of one's peoples' feelings, and subsequently the emotional intelligence to communicate in an empathetic way. As such, empathy lies at the heart of the ethos of political leadership and of honest authenticity, and so suggests a change in the philosophy of leadership.

We suggest that political communication is currently mono-dimensional, there is too much focus on the performative dimension. Political communication involves communicating the brand values deemed necessary to beguile citizens, appear better than the opposition and to win elections. But too often there is a lack of delivery, and the rhetoric is not sufficiently espoused through policies or experienced by citizens. Hence, we propose that political communication must not only be performative, embedded in codes of rhetoric, but it needs to be made real. Our three dimensions are experiential, citizens should feel their leaders are public servants, that the nation is one nation in which no-one feels marginalized or disenfranchised, and where all the diverse needs of a diverse community are understood and met as closely as possible. Where there are gaps between the service ethos rhetoric and delivery they need to be discussed and explained honestly and transparently. This more accountable mode of leadership necessitates a more three-dimension form of political communication.

\section{CONTRIBUTION AND FUTURE RESEARCH}

Whilst we understand that our thesis here may sound very optimistic and idealistic, we have the steadfast opinion that a more sustainable model of political communication is achievable and needed. At the heart of our argument, we do consider the conflictual nature of politics, the hard interests in societies and the continuous political struggle inherent to political life. Various studies have meticulously examined these implications (Beaufort, 2018; Schedler, 2021) as well as citizens unwillingness or inability to actively engage in public affairs (Hartley, 2010; MacKenzie \& Moore, 2020). Conflict and sporadic mass participation are core features of representative democracy, the problem is when these appear to be the default setting for civic engagement. As Schudson (1998) aptly suggests in his study The Good Citizen, it is the failure of the American press and political communication to facilitate a healthy political culture that have further weakened citizenship and the public sphere. It is in this context that we argue that a synergistic 
effort by all agents involve (political actors, media, citizens with different and varying responsibilities) is imperative to achieve positive change. In the current state of affairs (constant crises), there are political leaders who have understood the need for a more inclusive and empathetic communication (for example Jacinda Ardern), and studies have shown that citizens are more eager to participate in public life when they feel that their voices are heard and they feel part of a wider community (Chambers, 1995; Lehavot, Balsam, \& Ibrahim-Wells, 2009). Obviously, our model can only be applied in democratic societies where the political system and culture allow citizens' voices to be heard and where media can, at least to some extent, function independently of political interests, although perhaps we posit that our model should also be built in as a normative blueprint for democracy within transitional societies.

Hence, the intended contribution of this chapter is to further contribute to the conversation about reimagining political communication and ensuring that it promotes trust in democratic institutions. We share the view of many researchers that the trajectory it is on is undermining trust, however arresting that trajectory and proving empirically how differing strategies can advance democratic culture is more challenging. Studies of political leadership and communication style and rhetoric can however add important insights, particularly in relation to the communication styles around specific events. A few studies have highlighted differences in leadership style in relation to terrorist attacks, in particular the empathetic solidarity displayed by New Zealand prime minister Jacinda Ardern after the 2019 attack on a Christchurch Mosque (Besley \& Peters, 2020). Similarly, work has surveyed the communication styles of a variety of leaders facing the Covid-19 pandemic (Lilleker, Coman, Gregor \& Novelli, 2021). However, work structured specifically around the three dimensions of service ethos, inclusivity and empathy across a wider range of contexts would be insightful for understanding the links between leadership style and public attitudes. The latter aspect is particularly important in this respect. Linking not just public opinion data to the handling of crises or events of national significance, but a broader range of attitudes towards leaders and institutions would provide firmer grounding for understanding the role of leadership style in shaping the broader mood of a nation's citizens. Such research is needed as we need a normative model, perhaps a gold standard, against which the political communication of leaders can be measured. Censuring leaders for poor communication practice is often warranted and worthy, but often can be read as partisan point scoring. Having a standard which leaders should aspire to, and can be judged against, highlighting why failing to meet the standard does not just undermine the office of the leader but all the institutions of governance is a goal the academy should have in its sights. Therefore, through this intervention, we hope to start a conversation and a research agenda in order to reconfigure the thinking which shapes our political communication environments.

\section{REFERENCES}

Aristotle, Nicomachean Ethics, Book 2 (1103a17). Available at: http://www.perseus.tufts.edu/hopper/text?doc=Perseus\%3Atext\%3A1999.01.0054\%3Abook\%3D2

Aristotle. (2012). Rhetoric. [Translated by Robin Waterfield] Oxford: Acheron Press. 
Ball-Rokeach, SJ., Yong-Chan, K., and Matei, S. (2001). Storytelling Neighborhood: Paths to Belonging in Diverse Urban Environments. Communication Research, https://doi.org/10.1177/009365001028004003

Bay, A.H., \& Blekesaune, M. (2002). Youth, unemployment and political marginalisation. International Journal of Social Welfare, 11(2), 132-139.

Blake, A. (2016) ‘Is Hillary Clinton's ‘deplorables’ remark like Mitt Romney’s ‘47\%’ gaffe?' Washington Post, 10 September https://www.newsobserver.com/news/politics-government/article101078697.html

Beaufort, M. (2018). Digital media, political polarization and challenges to democracy. Information, Communication \& Society, 21(7), 915-920.

Blumler, JG. (2018). The Crisis of Public Communication, 1995-2017. Javnost: The Public, 25 (1-2), 8392.

Blumler, Jay G., Coleman, S., \& Birchall, C. (2017). Debating the Debates; How Voters Viewed the Question Time Special. London: Electoral Reform Society.

Blumler, Jay G., \& Gurevitch, M. (1995). The Crisis of Public Communication. London: Routledge.

Besley, T., \& Peters, M. A. (2020). Terrorism, trauma, tolerance: Bearing witness to white supremacist attack on Muslims in Christchurch, New Zealand. Educational Philosophy and Theory, 52(2), 109-119.

Bickford, S. (1996). The Dissonance of Democracy: Listening, Conflict and Citizenship. Ithaca, NY: Cornell University Press.

Castanho Silva, B., Vegetti, F., \& Littvay, L. (2017). The elite is up to something: Exploring the relation between populism and belief in conspiracy theories. Swiss political science review, 23(4), 423-443.

Castoriadis, C. (1983). The Greek polis and the creation of democracy, Graduate Faculty Philosophy Journal, 9 (2): 79-115.

Castoriadis, C. (1991). Philosophy, Politics, Autonomy. Oxford: Oxford University Press.

Caza, A. and Jackson, B. (2011) Authentic leadership. In A. Bryman, D. Collinson, K. Grint, B. Jackson \& M. Uhl-Bien (Ed.), The Sage Handbook of Leadership (pp. 352-364). Los Angeles CA: Sage.

Chambers, S. (1995). Feminist Discourse/Practical Discourse, in Johanna Meehan (ed.) Feminists Read Habermas: Gendering the Subject of Discourse, pp. 163-79. New York: Routledge.

Coleman, S. (2011). Representation and mediated politics: Representing representation in an age of irony. In K. Brants and K. Voltmer (Ed.), Political Communication in Postmodern Democracy: Challenging the Primacy of Politics (pp. 39-56). Basingstoke: Palgrave Macmillan. 
Cooke J.E., Eirich, R., Racine, N., \& Madigan, S. (2020). Prevalence of posttraumatic and general psychological stress during COVID-19: A rapid review and meta-analysis. Psychiatry Research, doi.org/10.1016/j.psychres.2020.113347

Curran, J., Iyengar, S., Lund, A.B., and Salovaara-Moring, I. (2009). Media Systems, Public Knowledge and Democracy: A Comparative Study. European Journal of Communication, 24 (1): 5-26.

Davis, A., Fenton, N., Freedman, D., \& Khiabanv, G. (2020). Media, Democracy and Social Change: Reimagining Political Communications. London: Sage.

De Beus, J. (2009). Populist leadership. In J. Kane, H. Patapan \& P. t’Hart (Ed.), Dispersed Democratic Leadership: Origins, Dynamics, and Implications (pp.83-104). Oxford: Oxford University Press).

Degerman, D., Flinders, M., \& Johnson, M. T. (2020). In defence of fear: COVID-19, crises and democracy. Critical Review of International Social and Political Philosophy, 1-22.

Enli, G. \& Rosenberg, L.T. (2018). Trust in the Age of Social Media: Populist Politicians Seem More Authentic, Social Media \& Society, 4 (1), 1-11. doi:10.1177/2056305118764430.

Fotopoulos, T. (2005). From (mis)education to Paideia. The International Journal of Inclusive Democracy, 2(1), 1-33.

Friedman, U. (2020), New Zealand's Prime Minister May Be the Most Effective Leader on the Planet. In The Atlantic. Available at: https://www.theatlantic.com/politics/archive/2020/04/jacinda-ardern-newzealand-leadership-coronavirus/610237/

Gerodimos, R., \& Justinussen, J. (2015). Obama's 2012 Facebook campaign: Political communication in the age of the like button. Journal of Information Technology \& Politics, 12(2), 113-132.

Habermas, J. (1989). The Structural Transformation of the Public Sphere: An Inquiry into a Category of Bourgeois Society. Cambridge: Polity Press.

Hartley, J. (2010). Silly Citizenship. Critical Discourse Studies, 7 (4), 233-248.

Helms, L. (2012). Democratic Political Leadership in the New Media Age: A Farewell to Excellence? The British Journal of Politics \& International Relations, 14, 651-670.

Hoffmann, M. L. (2000). Empathy and Moral Development: Implications for Caring and Justice. New York: Cambridge University Press.

Holroyd, M. (2021) Greek PM Kyriakos Mitsotakis accused of breaking COVID-19 rules for a second time. Euronews. Available at: https://www.euronews.com/2021/02/08/greek-pm-kyriakos-mitsotakis-accusedof-breaking-covid-19-rules-for-a-second-time

Jetten, J., Reicher, S. D., Haslam, S. A., \& Cruwys, T. (Eds.). (2020). Together Apart: The Psychology of COVID-19. London: Sage. 
Kemmers, R. (2017). Channelling discontent? Non-voters, populist party voters, and their meaningful political agency. European Journal of Cultural and Political Sociology, 4(4), 381-406.

Leith, S. (2011) You Talkin' To Me?: Rhetoric from Aristotle to Obama. London:Profile Books.

Lehavot, K., Balsam, K., and Ibrahim-Wells G.D. (2009). Redefining the American quilt: Definitions and experiences of community among ethnically diverse lesbian and bisexual women. Journal of Community Psychology 37(4):439 - 458

Lilleker, D.G. (2021). Communicating crisis: Political communication in the age of uncertainty. Keynote Address for ECREA Political Communication Division Conference, Bucharest, 26 March 2021.

Lilleker, D., Coman, I., Gregor, M., \& Novelli, E. (2021) (Eds). Political Communication and Covid-19: Governance and rhetoric in times of crisis. London: Routledge.

Luebke, S.M. (2020). Political Authenticity: Conceptualization of a Popular Term, The International Journal of Press/Politics, 1(19) doi: 10.1177/1940161220948013

MacKenzie, M. K., \& Moore, A. (2020). Democratic Non-Participation. Polity, 52(3), 430-459.

Margolis, M. \& Resnick, D. (2000). Politics as Usual: The Cyberspace “Revolution”. London: Sage.

McGuire, D., Cunningham, J.E.A, Reynolds, K., \& Smith, G.M. (2020). Beating the virus: an examination of the crisis communication approach taken by New Zealand Prime Minister Jacinda Ardern during the Covid-19 pandemic, Human Resource Development International, 23 (4), 361-379.

Miao, C., Humphrey, R., \& Qian, S. (2018). Emotional Intelligence and Authentic Leadership: A MetaAnalysis. Leadership and Organization Development Journal, 39(5), 679-690.

Moschonas, G. (2020). Paradigm shifts in the light of the past: the 1929 crash, the great recession of 2008 and the covid-19 crisis. openDemocracy. Available at: https://www.opendemocracy.net/en/can-europemake-it/paradigm-shifts-light-past-1929-crash-great-recession-2008-and-covid-19-

crisis/?utm source $=$ fb\&fbclid=IwAR2zpG0sGK-

2pgNx1bdLcZbPZsw6Jlc_KwqM3ePoNj9hEpSi1uX2bX2Y1FI

Mshvenieradze, T. (2013). Logos Ethos and Pathos in Political Discourse, Theory and Practice in Language Studies, 3 (11), 1939-1945.

Norris, P., \& Inglehart, R. (2019). Cultural backlash: Trump, Brexit, and authoritarian populism. Cambridge: Cambridge University Press.

Pajnik, M. (2006). Feminist Reflections on Habermas's Communicative Action. The Need for an Inclusive Political Theory. European Journal of Social Theory 9(3): 385-404.

Reiser, M. (2018). Abgehoben und entkoppelt?. In J. Brichzin, D. Krichewsky, L. Ringel, J. Schank, (Ed.), Soziologie der Parlamente (pp. 111-134). Wiesbaden: Springer VS. 
Rupar, V., Owen, T., \& Baker, S. (2015). Diversity, Inclusivity and the News: Coverage of the 2014 New Zealand General Election. Medianz, 15 (2), 1-26.

Schedler, A. (2021). Democratic Reciprocity. Journal of Political Philosophy, 29(2), 252-278.

Schudson, M. (1998). The Good Citizen. A History of American Civic Life. NY: The Free Press.

Shogan, C. J. (2009). The contemporary presidency: the political utility of empathy in presidential leadership. Presidential Studies Quarterly, 39(4), 859-877.

Shane, T. (2018). The Semiotics of Authenticity: Indexicality in Donald Trump's Tweets.

Social Media \& Society, 4 (3), 1-14. doi:10.1177/2056305118800315.

Smith, H. (2021). Greek PM criticised for lunch that breached Covid restrictions. The Guardian. Available at: https://www.theguardian.com/world/2021/feb/07/greek-prime-minister-criticised-for-lunch-with-up-to$\underline{40 \text {-people }}$

Social Mobility Commission (2021). Most people believe inequality has increased due to the pandemic. Available at: https://www.gov.uk/government/news/most-people-believe-inequality-has-increased-due-tothe-pandemic

Spinney, L. (2020). Inequality doesn't just make pandemics worse - it could cause them. The Guardian. Available at: https://www.theguardian.com/commentisfree/2020/apr/12/inequality-pandemic-lockdown

Sanders, K., \& Canel, M. J. (2013). Government communication: Cases and challenges. London: Bloomsbury Academic.

Stanford (2010). Aristotle's Rhetoric. In Stanford Encyclopedia of Philosophy. Available at: https://plato.stanford.edu/entries/aristotle-rhetoric/\#means

Steffens, N. K., Mols, F., Haslam, S. A., \& Okimoto, T. G. (2016). True to what we stand for: Championing collective interests as a path to authentic leadership. The Leadership Quarterly, 27(5), 726-744.

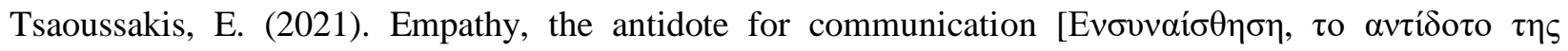

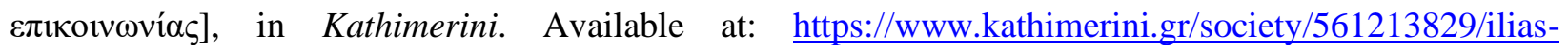
tsaoysakis-ensynaisthisi-to-antidoto-tis-

epikoinonias/?fbclid=IwAR3aBhOs1wNvw IIKFgxnNe2czY zIWsVYqI b1kTfncloulx -BrzwkY2s

United Nations. (2009). Vision for an Inclusive Society. Available at: https://www.un.org/esa/socdev/documents/compilation-brochure.pdf 
Van Dick, R., Lemoine, J. E., Steffens, N. K., Kerschreiter, R., Akfirat, S. A., Avanzi, L. Dumont, K., Epitropaki, O., Fransen, K., Giessner, S., Gonzales, R., Kark, R., Lipponen, J., Markovits, Y., Monzani, L., Orosz, G., Pandey, D., Roland-Lévy, C., Schuh, S. C., Sekiguchi, T., Song, L. J., Stouten, J., Tatachari, S., Valdenegro, D., van Bunderen, L., Vörös, V., Wong, S. I., Zhang, X-A., \& Haslam, S. A. (2018). Identity leadership going global: Validation of the Identity Leadership Inventory (ILI) across 20 countries. Journal of Occupational and Organizational Psychology, 91, 697-728.

Verzichelli, L. (2018). Elite circulation and stability. In J. Hingley, U. Hoffmann-Lange, \& H. Best (Ed.) The Palgrave handbook of political elites (pp. 573-591). London: Palgrave Macmillan.

Waheed, M., Schuck, A., de Vreese, C., \& Neijens, P. (2011). More different than similar: Values in political speeches of leaders from developed and developing countries. Journal of Intercultural Communication, 26, 7-7.

Wilson, J. Q., \& Banfield, E. C. (1971). Political Ethos Revisited, The American Political Science Review, 65 (4):1048-1062.

Whittle, A., Housley, W., Gilchrist, A., Mueller, F., \& Lenney, P. (2015). Category Predication Work, Discursive Leadership and Strategic Sensemaking. Human Relations, 68 (3): 377-407. doi:10.1177/0018726714528253.

Yang Li \& Mutchler, J.E. (2020). Older Adults and the Economic Impact of the COVID-19 Pandemic. Journal of Aging \& Social Policy, 32(4-5), 477-487.

Young, IM. (2000). Inclusion and Democracy. Oxford: Oxford University Press. 